\title{
遍是宗法性について
}

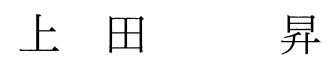

§1 玄焋は因の第一相 --- シャンカラスヴァーミンNyāyapraveśa（『因明入正理 論』）の“pakșadharmatva”---を「遍是宗法性」と訳し，これは伝統的には「遍じ て是れ宗が法たるの性」と読むとされる1)。しかし「遍」に対応する原語はこの Nyäyapraveśa のサンスクリット文に存在しないばかりか, ディグナーガの Pramānasamuccaya (-vrtti) (『集量論』) における因の第一相に相当する文 (anumeye ... sadbhāvo）にも存在しない. また，ディグナーガの Nyāyamukha（『因明正理門論』） はサンスクリット原文が散逸し, またチベット語訳も存在しないが, 玄奘は『因 明正理門論』では因の第一相に相当する表現を「宗法」と呼ぶのみである（cf.大 正 32, 1b6: 宗法於同品 謂有非有俱 於異品各三 有非有及二). また, 次の箇所でも第 一相 (下線部) は単に因が所比處すなわち宗（パクシャ）に存在することであり, 「遍」の字は見られない.

又比量中唯見此理. 若所比處此相審定 ${ }^{2)}$. 於餘同類念此定有. 於彼無處念此遍無. 是故由 此生決定解.（Ibid. 3a4）

Nyāyapraveśa は因の第一相について『因明正理門論』あるいは『集量論』と異 なった説を具体的に展開しているわけではない。そして，『因明正理門論』の翻 訳に先立つこと既に二年前（西暦 647 年）に『因明入正理論』を翻訳するに際し て「遍是宗法性」なる訳語を使用しているのであるから，玄牀はインドでの論理 学の学習を通して「遍」の付加の根拠を得ていたのであろう. 玄奘によるこの付 加の根拠を直接示すことは困難であるが, 関連する議論をインド論理学のテキス トに探すことは出来る.

先ず, Nyāya-Sūtral.2.4について Nyāyavärttikaで Uddyotakara は, 所立（=パク シャ）の一部分に存在する（sādhyaikadeśa-vrtti）因（似因）による16の論証例を挙 げている ${ }^{3)}$. 例えば, anityāh paramānavo 'gandhavattvāt（諸極微は無常である. 無香の 故に.）は, 因が所立の一部分および同類の一部分に存在しかつ異品の全体に存在 する（sādhya-tajjātīyaikadeśa-vrittir vipakșa-vyāpakah）（誤った）論証であり，また， sar- 
vam anityam mūrtatvād（一切は無常である. 質礙性の故に.）は, 因が所立の一部分に 存在し同品および異品がない（sādhyaikadeśa-vrtttir avidymāna-sapakșa-vipakṣah）（誤った） 論証である。（Nyāyadarśanam vol. 1, p.366-367）

また，Nyāya-Sütra 1.1.35 に関連するUddyotakara の主張の一つは，仏教徒の言 う因の第一相は因が宗の法（yo dharmah pakșasya）であることを規定するのみであ るから，因がパクシャの一部分に存在すること（pakșaikadeśa-vrtti）を排除できない とするものである (ibid. p.297)。 それに対し仏教側は evaによる限定（avadhāraṇa） によって，この ekadeśa-vrtti は排除できると反論する。ここで Uddyotakara は問う. その限定は 1) dharma eva pakșasya か, それとも2） pakșasya eva dharmaなのか, と.そして 1)，2）いずれの場合も pakșaikadeśa-vṛtti は排除できないとするのであ るが，このうち 1）の場合について，仏教側は次のように述べて自己の第一相を 弁護する。

atha punar vyāptir asyāvadhāraṇasyārthah dharma eva pakṣasyeti, na punar adharmo 'pi, yah punah pakșaikadeśavṛttir asāv adharmo ’pi (ibid. p.298, 1.2-3)

もしくは〔仏教徒は言う.〕その限定の意味は遍満（vyāpti）である。パクシャの法 (dharma) に他ならず，また非法（adharma）でもない，パクシャの一部分に存在するも の，それは非法であるということでもある.

この主張は誰のものであるかは定かでないが，第一相（pakșadharmatva）を満たす 因はパクシャ全体に遍満する（vyāpti）法（dharma）である，そしてそのようなパ クシャに遍満するものをこそパクシャの法（dharma）と呼ぶのであるとする立場 が（ニヤーヤ学派からの批判に答える形で）仏教側に存在したことを示す。玄牀の 「遍是宗法性」なる訳語にはこうした背景があったと考えられよう。

§2 パクシャの一部分にしか存在しないと考えられる因による論証をディグ ナーガはどう扱ったか. 先ず，そうした論証の代表的なものに，

（A）諸樹木は思慮を有する。眠る故に ${ }^{5)}$. がある。

樹木には眠る（葉が萎む: patra-sańkoca）ものと眠らないものとがある. 従って， 「眠る」という属性（dharma）はパクシャ（諸樹木）の一部分にしか存在せず，上 の意味での宗法性（pakșadharmatva: 遍是宗法性）を満たしていない.

同様な論証として,

（B）声は無常なり. 勤勇無間所発性の故に. 
を挙げることができる．声（śabda）には人の声もあれば風で折れた枝の音なども あるが，勤勇無間所発性なる法（dharma）は人の声に存する属性であるとは言え ても，風で折れた枝の発する音に存する属性とは言えない，従って，いま（B) における「声」を「一切の声」とするならば，勤勇無間所発性はパクシャ（声） 全体に遍満する法ではなくなり，(A）と同様に因の第一相（遍是宗法性）を満た さない．ところが，『集量論』では，(A）は論証としてその正当性を認められな い（cf. 北川 p.334）にもかかわらず，（B）は論証としての正当性が認められている (cf. 北川p.336)。（B）に関連して北川（p.337）は次のように述べる.

立論者が「声は無常なり．勤勇無間所発性の故に」という論証式を立てた時, 対論者が 「勤勇無間所発性は風によって惹き起された樹木の枝の折れから生じた声には存しない」 と言いさえすればそれで原立論中の因が不成因であることは指摘されているわけであり， 論難は一応成功しているはずである，又，この論難に対する立論者の正しい反駁は「成 程 śabda という語には人の声という意味とともに物の音という意味も存するが, 今問題と なっている śabda は前の意味での śabda であるからその非難は当たらない」であるべきで ある。

しかし，それでは（A）において「今問題となっている樹木は眠る樹木である」 と言いさえすれば，(A）も論証として成立するはずである，我々は，ここで目を 中国・日本の因明に転じることにする.

§ 3 基の『因明入正理論疏』には「宗法」と「遍」の四種類の関係が挙げられ ている（大正 44, 103b).

(1)宗法而非遍（宗法にして遍に非ず）；(2)遍亦宗法（遍にして亦宗法）

(3)非遍非宗法（遍にも非ず宗法にも非ず）；(4)遍非宗法（遍にして宗法に非ず） 基は(2)のみを正因とし（唯第二句遍亦宗法是正因相〈103c 9$\rangle$ ), (1)および(3)を不成因 （宗法而非遍者四不成中皆一分摂〈103b19〉, 非遍非宗法者四不成中升全分過〈103b29〉）， また(4)句はあり得ないとする（必無是遍非宗法〈103bl3〉）。鳳潭（1659-1738）の『因 明論疏瑞源記』によれば, (1), (2), (3)のみならず(4)句をも認める立場も存在した とされるが，今興味深いのは(2)と(3)をのみ認め，(1)の存在を認めない立場（立二 句）である. 即ち「纂要破云. 或立二句云」として,

無是宗法而非遍. 如立一切声無常. 勤勇発因. 望内声上遍是宗法. 若望外声非遍非宗法 ${ }^{6}$. 是れ宗の法にして遍に非ざること無し，一切の声は無常なるべしと立つるが如し．勤勇 発の因, 内声の上に望んでは遍じて是れ宗の法なり．若外声に望んでは遍に非ず宗の法 
に非ず。

これは以下のように破せられる。

此亦不然．総立内外一切声宗．勤勇発因．不可別望内外声分為是為非故．勤勇発必是無 常得名宗法但非遍故 ${ }^{7)}$.

此れ亦然ず．総じて内外一切の声の宗を立つ． 勤勇発の因，別に内外の声に望んで分か ちて是と為し非と為すべからざる故に，勤勇発なるは必ず是れ無常なれば宗の法にして 但だ遍に非ずと名づくことを得るが故に。

この議論で内声（cf.『因明入正理論疏』105a, 108b; 『明燈抄』205bl9）は人の声などを， 外声は風で折れた枝の音などを指す。内声は勤勇無間所発であるが, 外声は違う. 敵者たる立二句の立場は声無常の論証において「勤勇無間所発性」を因とすると き，パクシャ「声」は内声か外声かのいずれかでなければならないとするもので ある。もしパクシャが内声であるなら，勤勇無間所発性はパクシャに遍満する. 他方，もしパクシャが外声であるなら勤勇無間所発性はパクシャの法 (dharma) たり得ない，従って，パクシャの法すなわち宗法でありながらパクシャを遍満し ない因（不成因）はあり得ない。こうして，立二句の立場は(1)宗法而非遍（宗法に して遍に非ず）を認めない.

この立二句の立場は，evaによる限定（dharma eva pakșasya）を第一相に持ち込み， さらにその限定を vyāpti（遍満）と解する先に見たインド仏教徒の立場と同等で あると言うことができよう。

ところで，論証（A）「諸樹木は思慮を有する，眠る故に」は鳳潭によっても(1) 宗法而非遍の夕イプの不成因による論証とみなされていると考えられる.

秋篠云 ${ }^{8)}$. 若因不遍宗有法上等者. 若立宗寬立其因狭非因成宗. 如外道師立. 一切草木応 有心識. 以有眠覚故. 如合歓樹. 此因不遍宗有法上. 此所不遍便是非因能成於宗 ${ }^{9)}$.

秋篠云はく．「若し因は宗の有法の上に遍ぜざれば」(『因明入正理論疏』103b1）等とは. 若し宗を立つることは寛く，其の因を立つること狭きは，因は宗を成ずるに非ず，外道 の師「一切の草木は応に心識を有すべし，眠覚を有するを以ての故に，合歓樹の如し」 と立つるが如し．此の因は宗の有法の上に遍ぜず．此の遍ぜざる所便ち是れ因の能く宗 を成ずるに非ず。

下線部には明らかに外延の広狭が語られていると思える。合歓樹のような眠覚を 有する樹は草木の一部分の種類にすぎない，従って，「有眠覚」なる因はパクシャ （宗）たる「一切草木」に対して非遍である。 そして鳳潭は「立三句即今疏主 ...」 （六十六左）と述べるのであるから，疏主である基の立場に立つ限り，この因は(1) 
宗法而非遍と認められる.

一方，立二句の立場は(1)宗法而非遍を認めないのであるから，(A）において， パクシャたる「諸樹木」は眠る樹木と眠らない樹木いずれか一方の種類を意味し ていなければならない。これは, 立二句の立場からは, 声無常の論証（B）にお いて，パクシャ「声」は内声か外声かのいずれかの種類に限定されたのと同じで ある。

立二句の立場は，パクシャの法（dharma）は必ずパクシャを遍満する (vyāpti) と言い換えることができるであろう。そしてこれは既に見たように，Nyāyavārtti$k a$ に登場する仏教徒の立場なのである.

立二句の立場では，パクシャを遍満する法（dharma）のみが「宗法（pakșa-dharma)」なのであり, 他方立三句の立場からは, パクシャの一部分にのみ存在する 法もまた「宗法」である. しかし, 立二句, 立三句いずれの立場にせよ, 正因は パクシャに遍満している法（dharma）でなければならない，すなわち「遍是宗法 性」を満たしていなければならない。従って, 論証（B）を正当化するためには, パクシャ「声」を内声（人の声など）に制限することが必要であり，逆に論証（A） を非正当化するためにはパクシャを「眠る樹」にのみ制限することは避けなけれ ばならない.

基が立三句の立場 ${ }^{10)}$ であったように，我々も通常は立三句の立場に立っている ように思う。(1)の宗法而非遍なる因（不成因）を認めないことには無理があるよ うに見える。しかし，上で論証（B）の正当化 ${ }^{11)} に$ 関連して北川の場合に見たよ うに，時に我々は立二句の立場に立たざるを得ないのである.

§4 論証（A）および（B）において，「樹木」にしろ「声」にしろ，それらは 個々の樹木や個々の声から成る全体を意味していると考元られる。して，「眠 る」という属性（dharma）あるいは「勤勇無間所発性」という属性は先ず以て個々 の樹木あるいは個々の声についての dharma と考えられる。 そうであればこそ， パクシャの一部分にのみ存在する法 (dharma), 言い換えれば基の言う(1)の宗法而 非遍（宗法にして遍に非ず）なる法の存在が可能なのである。しかし，「立二句」 者は(1)のイプの法を認めない.すなわち, パクシャの法は必ずパクシャに遍満 （vyāpti）すると見る。ここで，もしパクシャを個体の集合として発想するなら， その集合の一部分（真部分集合）にのみ存在する法が認められない根拠が不明で ある。たとえば，村上専精（p.322）は次のような，(1)のタイプの不成因による論 
証を挙げる。

宗 日本人は皆仏教徒なるべし

因 仏法僧の三宝を恭敬するが故に

これは一分の両俱不成とされるが，その理由を次のように解説している（do.）.

宗ノ前名辞日本人ト云中ニテ其一部分ハ三宝习恭敬シ其一部分八三宝ヨ恭敬セザルカ故 ナリ

この解説に明らかなように，因（「仏法僧の三宝を恭敬する」）は(1)のタイプの法と 認められている。一方，立二句の立場は少なくともこのような法を宗法とは認め ないが，それは如何にも不自然である。しかし，以下のように，立二句の立場が 自然に成り立つような場面が考えられる。

いま，或る法（dharma）がパクシャに遍満（vyāpti）するということを，パク シャそのものおよびパクシャの任意の部分に当該の法が存在することとして解釈 してみる。例えば，コップ一杯の青色の水をパクシャとするとき，青なる法はこ のパクシャのどの部分にも存在すると同時にパクシャそのものにも存在する。も ちろん，現実の問題としては「部分」を水の分子レベルまで分割すれば，もはや その部分には青なる法は存在しなくなるであろうが，論理的には，分子・原子を 設定しない青色の「水」すなわち，どこまで細分しても青い「水」を考えること は可能である。 あるいは，水の分子・原子そのものが青色であるという状況を設 定することも可能である。いずれにせよこれらの場合，青なる法は真にパクシャ に遍満 (vyāpti) しているのである ${ }^{12)}$.

このような法（青）とパクシャ（コップ一杯の青色の水）を考えれば，パクシャ において存在する法は同時にパクシャのどの部分にも存在する法である, すなわ ちパクシャに遍満 (vyāpti) する法である ${ }^{13)}$.

$\S 5$ 集合 (class) には distributive な集合と collective な集合が区別されるという ${ }^{14)}$. 一般に述語論理学の意味解釈に用いられる集合は distributiveである。 distributive な集合の場合，最も基本的な関係は集合とその要素（元）の関係であり通常 $\in$ で 表される。たとえば， $\mathrm{x} \in \mathrm{M}$ は「 $「 \mathrm{x}$ は集合 $\mathrm{M}$ の要素である」ことを意味する。集 合 $\mathrm{P}$ と $\mathrm{M}$ を所与として, もし $\mathrm{M}$ の全ての要素が $\mathrm{P}$ の要素でもあるなら, $\mathrm{M}$ は $\mathrm{P}$ の部分集合（M は $\mathrm{P}$ に含まれる）と呼ばれ， $\mathrm{M} \subseteq \mathrm{P}$ などと表す、 $\mathrm{M}$ が $\mathrm{P}$ の部分集 合であるとき, $\mathrm{P}$ の要素ではあるが $\mathrm{M}$ の要素ではないものが少なくとも一つ存在

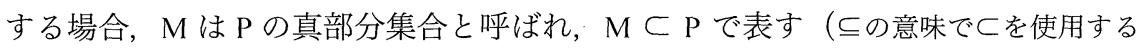


書物もしばしば見られる).また， $\mathrm{M} \subseteq \mathrm{P}$ かつ $\mathrm{P} \subseteq \mathrm{M}$ であるとき，すなわち $\mathrm{M}$ と $\mathrm{P}$ が同じ要素から成るとき，M と P を同一であると呼び， $\mathrm{M}=\mathrm{P}$ で表す.

先に見たように，鳳潭が(1)宗法而非遍のタイプの不成因に関連して秋篠云とし て述べる「立宗寛立其因狭」は，因 $\subset$ 宗と表すことができるであろう。さらに， (2)遍亦宗法なる因，すなわち第一相を満たす因の場合は，因＝宗あるいは宗 $\subseteq$ 因と表せるであろう（例えば，声し所作）。

一方, collectiveな意味の集合については Mereologyと呼ばれる集合論が S.Lesniewski によって創始された。 そこでは，「部分（is [a] part of）」が最も基本 的な関係となる。そして，物質名による意味解釈（a mass interpretation）が，この集 合論の原理をすべて満足するとも言われる (Simons, p.158).

因の第一相（遍是宗法性）の規定を自然に満たすものは，上で取り上げたよう に「水」のような物質名の対象とそれに遍満する法の間の関係に見られる。つま り，パクシャ（全体）の所有する法はそのままあらゆる部分の所有する法である といった「立二句」的状況が成り立つ。声無常の論証に関連して，宗（パクシャ） たる声を個々の声の総体（総和）と見て三支作法における因支 --- 事実上因の第一 相 --- を宗 $\subseteq$ 因といった包摂関係によって解釈することには問題があることを筆 者は「遍充と周延」（印仏研52-2, 2004）で論じたが, 「パクシャを表示する名辞の 意味をどのように捉えるべきか」については課題としていた．本稿はこの問題に 対する一応の解答 --- パクシャの物質名モデル --- である.

なお，このモデルによれば，パクシャの任意の部分を同品に取ることができる から，声をパクシャとする論証において，「所聞性」を不共不定因と見るべき必 然性はなくなる。詳細は別稿を期すが, ラトナーカラシャーンティが『内遍充論』 の末尾において，「一切声」をパクシャとするとき，一つの声を事実上の喻例と 見て, 「所聞性」を正因と認める議論 ${ }^{15)}$ は, 我々の観点からも甚だ興味深い.

参考文献 : 宇井伯寿『東洋の論理』青山書院 1950; 『印度哲学研究』第五（1929〈岩波 1965〉)。村上専精『活用講述因明学全書』哲学書院 1891. 中村元訳 因明入正理論疏, 『国訳一切経』論疏部二十三. 北川秀則『インド古典論理学の研究 --- 陳那の体系 ---』鈴 木学術財団 1965 (臨川 1985). 岡崎康浩『ウッドヨータカラの論理学』平楽寺書店 2005. Nyāyadarśanam vol. 1, Rinsen. 鳳潭『因明論疏瑞源記』〈寶永八年再治〉（山城屋文 政堂). D.H.Ingalls, Materials for the study of Navya-Nyāya Logic, 1951. Peter Simons, PARTS --- A Study in Ontology--- Oxford 1987.

1）宇井 1950, p.146. Cf. 村上 p.237「遍じて是れ宗が法たる性」; 中村 p.49「遍じて是れ 
宗の法たる性」２）宇井（1929, p.621）は「審定」を基の『因明入正理論疏』(cf. 大 正巻 44,97a26) 等により「定遍」に改め,「若し所比の處に此の相が定んで遍ぜば」と読 んでいる。しかし，「審定」に該当する『集量論』チベット語訳は nes par bzun (Kanakavarman 訳, 北川 p.521; 北川訳「確認せられた」ibid., p.267) であり「審定」を「定遍」に 改めることは行き過ぎであろう。

3) Cf. 北川 p.398, 注 1084 .

4）この主張がディ グナーガのものかどうかは分からない. 実際, 岡崎 (2005, p.66) が述べるょうに「Dinnāga の場合，立証対象，つまり立証されるべき属性の基体となるものの領域の考察がなされ ていない」からである.

5）関連するサンスクリット文，チベット文ならびに漢訳 は以下のようである. sacetanā taravah svāpāt (Nyāyapraveśa-vrtti, GOS No.38, p.23, 1.23) ; śin sems pa can la ñal ba bshin no（Pramāṇasamuccaya-vrtti, Kanakavarman 訳, 北川 p.548）；叢林 皆有思慮, 有睡眠故（『因明正理門論』大正 $32,4 \mathrm{~b} 19)$ 6) 鳳潭『因明論疏瑞源記』 (巻二, 六十七右)。秋篠寺善珠『明燈抄』(大正 No. 2270, vol.68, 264c23) にほぼ同一の文 が載っている.

7）鳳潭（巻二, 六十七右)。『明燈抄』(大正 264c26）にほぼ同一文.
8） Cf.『明燈抄』 $263 \mathrm{c} 24$
9）鳳潭（巻二，六十四左）
10）基は論証
(B) につい て, 勤勇無間所発性は外声に於いて無く，これは一分両俱不成の過であるとしている （『因明入正理論疏』大正 121a） 11）論証（B）は九句因の第八句に配されており（cf. 北川 p.189), ディグナーガがこの論証に正当性を認めていたことは疑問の余地がない. 12）二ヤーヤ・ヴァイシェーシカでは性質（guna）は実体（dravya）に内属（samavāya） するとされるが,この内属は vyāpya-vrtti（of complete occurrence）の関係であると新ニヤー ヤ学派では一般的に解釈されるという (cf. Ingalls, p.75)。しかしまた, Raghunātha は場合 によっては内属が avyāpya-vrtti（of incomplete occurrence）の関係のこともあるとしたとい う。すなわち, Raghunātha considered that inherence might be a relation of incomplete occurrence too, for redness is said to inhere in a red pot, yet when we break the pot we may find that only outsides of the shards are red, the rest black. Again, a black cow may have a white face. (ibid. p.73, n.152) Ingalls のこの説明から, 実体への色の内属は新ニヤーヤ学派では（Raghunātha な ぞを別にすれば）通常は vyāpya-vrtti として考光られており，それは実体のどの部分にも 当該の色が存在することと理解できる：ただし，ニヤーヤ・ヴァイシェーシカでは極微 論（原子論）を採るのであるから，「部分」とは極微どまりではある。しかし，極微もま た色を有するとされるのであるから色の遍満性（vyāpti）は成り立つ。1 13）このよ うな法（dharma）は現代の論理学者が dissective と呼ぶ述語に相当すると考光られる. Cf. P. Simons, p. 139. 14）この用語は Lesniewskiによるが，集合の区別そのものはF Frege にまで遡るという。. Cf. Simons, p.28, n.19. 15） Cf. 梶山雄一「ラトナーカラシャーン テイの論理学書」仏教史学 8-4 (1960)

$$
\text { 〈キーワード〉 ディグナーガ, ラトナーカラシャーンティ, 鳳潭, merology }
$$

(目白大学教授, 博士 (文学)) 
As is well known, Buddhism and Jainism share many common elements in their phraseology. The subject has been often investigated. For an investigation of the close parallels which can be traced between Pāli and Ardhamāgadhī texts, see H. Nakamura, "Common Elements in Early Jain and Buddhist Literature”, in Indologica Taurinensia vol.XI (1983), pp. 302-330 (Proceedings of the International Symposium on Jaina Canonical and Narrative Literature. Strasbourg, 16th-19th June 1981); K. Mizuno,"Hokkukyō no kenkyū" Shunjūsha Tokyo, 1981.; W. B. Bollé, "Reverse Index of the Dhammapada, Suttanipāta, Theragāthā and Therīgāthā Pādas with Parallels from Ayārañga, Sūyagaḍa, Uttarajjhāyā, Dasaveyāliya and Isibhāsiyāiṃ”, Studien zur Indologie und Iranistik, Monographie 8, Reinbek 1983 ; C. Caillat, "Jainology in Western Publications II”, in Jain Studies in Honour of J. Deleu, ed. by R. Smet and K. Watanabe. Tokyo, 1993, especially pp. 50-51. In this small paper, I would like to indicate comparable passages which seem to have been overlooked so far.

\section{On the Pervasion of hetu in paksa}

Noboru UEDA

In connection with the first condition of hetu (logical reason) some classical Chinese and Japanese treatises dealing with Buddhist logic refer to an opponent who argues that every pakșa-dharma necessarily pervades the pakșa and there cannot be a paksa-dharma that exists only in a part of the paksa. Logically speaking, however, the position of the opponent, it seems to me, can be that of Dignāga. In order to understand the position, the present paper proposes a mass interpretation, according to which the paksa is considered to be a mass of a certain kind of substance designated by a mass term such as "a cup of blue water", and the pakș-dharma is considered a property of the mass, such as "blue". 